\title{
TECHNICAL EDUCATION FOR LOWER SECONDARY LEVEL AND ITS REFLECTION IN DIDACTIC FACILITIES TEXTBOOKS
}

\section{Danka Lukáčová}

\begin{abstract}
For the subject of technology (technical education) at lower secondary level education teachers have used since 1999 one textbook and to the 2012 the second textbook was released. We have examined how the didactic equipment's of these books is and so we compared the new with the old one. For this purpose we used the method according to J. Prucha. Since the coefficient of didactic equipment from 2012 textbooks is $8 \%$ higher, it can be stated that the didactic usefulness of a new textbook is greater.
\end{abstract}

Key words: textbook, technology education, didactic equipment, basic school

\section{TECHNICKÉ VZDELÁVANIE NA NIŽŠOM SEKUNDÁRNOM STUPNI A JEHO REFLEXIA V DIDAKTICKEJ VYBAVENOSTI UČEBNÍC}

Resumé: V súčasnosti je často diskutovaná kvalita nových učebníc pre základné i stredné školy. V predmete technika (technická výchova) na nižšom sekundárnom stupni vzdelávania používali učitelia od r. 1999 jednu učebnicu a až v r. 2012 bola vydaná druhá učebnica. Zist’ovali sme, aká je didaktická vybavenost' týchto učebníc a z tohto pohl'adu sme porovnávali novú učebnicu so starou. Na tento účel sme použili metodiku podl'a J. Průchu. Ked’že celkový koeficient didaktickej vybavenosti učebnice z r. 2012 je o 8 \% vyšší, je možné konštatovat', že didaktická využitel'nost' novej učebnice je lepšia.

Klíčová slova: didaktická vybavenost', učebnica, základná škola, technické vzdelávanie.

\section{1 Úvod}

Technicky orientované predmety na nižšom sekundárnom stupni zastupoval na Slovensku do r. 1989 vyučovací predmet pracovné vyučovanie. Predmet sa vyučoval v každom ročníku základnej školy s hodinovou dotáciou dve hodiny za týždeň. Vyplývalo to zo samotného zamerania predmetu, ktorý $\mathrm{v}$ prvom rade zabezpečoval pracovnú výchovu na základných školách a vychovával k práci, a to dôsledne polytechnicky. Pre výučbu predmetu boli vydané učebnice - pre každý ročník zvlášt'. Po významných politických a spoločenských zmenách na Slovensku a v Čechách v r. 1989 sa zmeny $\mathrm{v}$ spoločnosti odrazili aj $\mathrm{v}$ školstve. Nastalo obdobie humanizácie školstva, na ktoré doplatilo technické vzdelávanie na nižšom sekundárnom stupni znížením časovej dotácie predmetu v 7. a 8. ročníku základnej školy na jednu hodinu týždenne (a úplným zánikom predmetu na gymnáziách). Tento trend $\mathrm{v}$ d’alších rokoch pokračoval až do reformy v r. 2008, ked' technické vzdelávanie na nižšom sekundárnom stupni zostalo oklieštené na dve hodiny na celom vzdelávacom stupni. V celom období rokov 1989 - 2008 bola vydaná jediná učebnica technickej výchovy. Učebnica vyšla v prvom vydaní v r. 1999 vo vydavatel'stve EXPOL Pedagogika, spol. s. r. o. v Bratislave. Spracoval ju desat'členný autorský kolektív pod vedením Ivana Krušpána. Učebníc bolo od začiatku na školách málo - väčšinou školy dostali učebnice $\mathrm{v}$ počte $30 \mathrm{ks}, \quad \mathrm{z}$ čoho vyplývala zložitá organizácia vyučovania - učitelia nosili učebnice na vyučovacie hodiny a žiaci s nimi nemohli doma pracovat'.

V r. 2012 vyšla nová učebnica pre technické vzdelávanie na nižšom sekundárnom stupni učebnica predmetu technika. Prvé vydanie vyšlo vo vydavatel'stve TBB, a. s v Banskej Bystrici. Spracoval ju autorský kolektív Lubomír Žáčok, Martin Kučerka, Ján Pavlovkin, Milan Durišs.

Nakol'ko v súčasnosti prebiehajú dlhé diskusie o kvalite učebníc na základných a stredných školách, rozhodli sme sa o zhodnotenie „porevolučných“ učebníc určených pre technické vzdelávanie na nižšom sekundárnom stupni. $\mathrm{Na}$ tento účel sme použili metodiku J. Průchu (Průcha, 1998), ktorú pre hodnotenie didaktickej vybavenosti učebníc už použili aj iní odborníci (Pillingová, M., 2011). 


\section{Použitá metodika}

$\mathrm{V}$ štruktúre učebnice rozlišujeme 36 komponentov. Každý z komponentov plní určitú špecifickú funkciu a $\mathrm{k}$ tomu používa špecifický spôsob svojho vyjadrenia (verbálny, alebo obrazový). Ktorúkol'vek učebnicu možno vyhodnotit' na základe toho, ktoré komponenty sú v nej zastúpené. Jednotlivé komponenty sú ešte rozčlenené do troch skupín podl'a príslušnej didaktickej funkcie komponentov do dvoch podskupín podl'a spôsobu vyjadrenia určitého komponentu v učebnici.

Aparát prezentácie učiva obsahuje:

Verbálne komponenty

1. výkladový text

2. výkladový text sprehl'adnenie (prehl'adová schémy, tabul'ky a i. k výkladu učiva)

3. zhrnutie učiva $\mathrm{k}$ celému ročníku

4. zhrnutie učiva k témam (kapitolám, lekciám)

5. zhrnutie učiva $\mathrm{k}$ predchádzajúcemu ročníku

6. doplňujúce texty (dokumentačný materiál, citácie z prameňov, štatistické tabul'ky a iné)

7. poznámky a vysvetlivky

8. podtexty k vyobrazeniam

9. slovníčky pojmov, cudzích slov a i. (s vysvetlením)

Obrazové komponenty

1. umelecké ilustrácie

2. náukové ilustrácie (schematické kresby, a i.)

3. fotografie

4. mapy, kartogramy, plány, grafy, diagramy a i.

5. obrazové prezentácie farebné (t. j. použitie najmenej jednej farby odlišnej od farby bežného textu)

Aparát riadiaci učenie obsahuje:

Verbálne komponenty

1. predslov (úvod do predmetu, ročníka pre žiakov)

2. návod na prácu s učebnicou (pre žiakov a/alebo učitel'a)

3. stimulácia celková (podnet na zamyslenie, otázky pred celkovým učivom k ročníka)

4. stimulácia detailné (podnet na zamyslenie, otázky pred alebo v priebehu lekcií, tém)

5. odlíšenie úrovní učiva (základné - rozširujúce, povinné - nepovinné a pod.)

6. otázky a úlohy za témami lekcií

7. otázky a úlohy k celému ročníku (opakovanie)

8. otázky a úlohy $\mathrm{k}$ predchádzajúcemu ročníku (opakovanie)

9. inštrukcie $\mathrm{k}$ úlohám komplexnejšej povahy (návody $\mathrm{k}$ pokusom, laboratórnym prácam, pozorovaniam, a i.)

10.námety pre mimoškolské aktivity s využitím učiva 11.explicitné vyjadrenie ciel'ov učenia pre žiakov

12.prostriedky a/alebo inštrukcie na sebahodnotenie žiakov (testy a iné spôsoby hodnotenia výsledkov učenia)

13.výsledky úloh a cvičení (správne riešenie, správne odpovede a pod.)

14.odkazy na iné zdroje informácií (bibliografie, odporúčaná literatúra a i.)

Obrazové komponenty

1. grafické symboly označujúce určité časti textu (definície, pravidlá, úlohy, cvičenia a i.)

2. použitie špeciálne farby pre určité časti verbálneho textu

3. použitie špeciálneho písma (tučné písmo, kurzíva a i.) pre určité časti verbálneho textu

4. využitie prednej alebo zadnej obálky (predsádky) pre schémy, tabul'ky a iné

Aparát orientačný obsahuje:

Verbálne komponenty

1. obsah učebnice

2. členenie učebnice na tematické bloky, kapitoly, lekcie a i.

3. marginálie

4. register (vecný, menný, zmiešaný)

Táto vyššie uvedená štruktúra je východiskom pre výpočet didaktickej vybavenosti učebníc podla nasledujúcej procedúry. $\mathrm{V}$ konkrétnej učebnici zistujeme výskyt jednotlivých štruktúrnych komponentov. Zaznamenávame, či určitý komponent $\mathrm{v}$ danej učebnici je alebo nie je využitý, bez ohl'adu na početnost' využitia. Na základe zistených údajov vypočítame čiastkové koeficienty, ktoré charakterizujú didaktickú vybavenost' učebnice:

1. koeficient využitia aparátu prezentácie učiva,

2. koeficient využitia aparátu riadiaceho učenia,

3. koeficient využitia aparátu orientačného,

4. koeficient využitia verbálnych komponentov,

5. koeficient využitia obrazových komponentov.

Nakoniec vypočítame celkový koeficient didaktickej vybavenosti učebnice. Všetky uvedené koeficienty počítame ako percentuálny podiel počtu skutočne využitých komponentov $\mathrm{z}$ počtu možných komponentov. Podobne vypočítame koeficient celkovej didaktickej vybavenosti učebnice ako podiel realizovaných komponentov $\mathrm{Z}$ počtu všetkých možných komponentov. Pri hodnotení platí: čím je hodnota určitého koeficientu vyššia, tým je aj didaktická vybavenost' učebnice ( $\mathrm{v}$ príslušnej zložke štruktúry) vyššia.

Konečným krokom analýzy je interpretácia hodnôt koeficientov. Pomocou koeficientov možno presne určit', ako konkrétne učebnice využíva, resp. nevyužíva možnosti z existujúceho 
repertoáru štruktúrnych komponentov. $\mathrm{Na}$ základe toho možno potom nedostatočnú vybavenost' učebníc koordinovat'. Týmto spôsobom je možné vykonávat' porovnávacie hodnotenie didaktickej vybavenosti učebníc rôznych ročníkov, predmetov, druhov škôl, učebníc vydaných rôznymi vydavatel'stvami, učebníc rôznych krajín.
4 Výsledky hodnotenia učebníc

Zastúpenie jednotlivých komponentov učebníc sme zhrnuli a zaznamenali do prehl'adných tabuliek $(1-4)$. V tabul'kách sme kvôli prehl'adnosti označili číslom 1 učebnicu od I. Krušpána a kol. a číslom 2 učebnicu od L'. Žáčoka a kol.

Tabul'ka 1 Porovnanie komponentov aparátu prezentácie učiva

\begin{tabular}{|l|c|c|}
\hline & 1. učebnica & 2. učebnica \\
\hline Aparát prezentácie učiva & $\mathbf{1 2}$ & $\mathbf{1 2}$ \\
\hline Verbálne komponenty & 7 & 7 \\
\hline Výkladový text prostý & $\mathrm{A}$ & $\mathrm{A}$ \\
\hline Výkladový text sprehl'adnený & $\mathrm{A}$ & $\mathrm{A}$ \\
\hline Zhrnutie učiva k celému ročníku & $\mathrm{N}$ & $\mathrm{N}$ \\
\hline Zhrnutie učiva k témam & $\mathrm{A}$ & $\mathrm{A}$ \\
\hline Zhrnutie učiva k predchádzajúcemu ročníku & $\mathrm{N}$ & $\mathrm{N}$ \\
\hline Doplňujúce texty & $\mathrm{A}$ & $\mathrm{A}$ \\
\hline Poznámky a vysvetlivky & $\mathrm{A}$ & $\mathrm{A}$ \\
\hline Podtexty k vyobrazeniam & $\mathrm{A}$ & $\mathrm{A}$ \\
\hline Slovníčky pojmov, cudzích slov & $\mathrm{A}$ & $\mathrm{A}$ \\
\hline Obrazové komponenty & 5 & 5 \\
\hline Umelecká ilustrácia & $\mathrm{A}$ & $\mathrm{A}$ \\
\hline Náuková ilustrácia & $\mathrm{A}$ & $\mathrm{A}$ \\
\hline Fotografie & $\mathrm{A}$ & $\mathrm{A}$ \\
\hline Mapy, kartogramy, grafy, ... & $\mathrm{A}$ & $\mathrm{A}$ \\
\hline Obrazová prezentácia farebná & $\mathrm{A}$ & $\mathrm{A}$ \\
\hline
\end{tabular}


Tabul'ka 2 Porovnanie komponentov aparátu riadiaceho učenie

\begin{tabular}{|l|c|c|}
\hline & 1. učebnica & 2. učebnica \\
\hline Aparát riadiaci učenie & $\mathbf{7}$ & $\mathbf{1 1}$ \\
\hline Verbálne komponenty & 4 & 8 \\
\hline Predhovor & $\mathrm{A}$ & $\mathrm{A}$ \\
\hline Návod pre prácu s učebnicou & $\mathrm{N}$ & $\mathrm{A}$ \\
\hline Celková stimulácia & $\mathrm{A}$ & $\mathrm{N}$ \\
\hline Stimulácia detailná & $\mathrm{N}$ & $\mathrm{A}$ \\
\hline Odlíšenie úrovní učiva & $\mathrm{A}$ & $\mathrm{A}$ \\
\hline Otázky a úlohy za témami & $\mathrm{N}$ & $\mathrm{A}$ \\
\hline Otázky a úlohy za celý ročník & $\mathrm{N}$ & $\mathrm{N}$ \\
\hline Otázky a úlohy k predchádzajúcemu ročníku & $\mathrm{N}$ & $\mathrm{N}$ \\
\hline Inštrukcie pre úlohy komplexnejšej povahy & $\mathrm{N}$ & $\mathrm{A}$ \\
\hline Námety pre mimoškolskú činnost's využitím učiva & $\mathrm{N}$ & $\mathrm{N}$ \\
\hline Explicitné vyjadrenie ciel'ov učenia pre žiakov & $\mathrm{A}$ & $\mathrm{N}$ \\
\hline Prostriedky a inštrukcie na sebareflexiu pre žiakov & $\mathrm{N}$ & $\mathrm{N}$ \\
\hline Výsledky úloh a cvičení & $\mathrm{N}$ & $\mathrm{A}$ \\
\hline Odkazy na iné zdroje informácií & 3 & 3 \\
\hline Obrazové komponenty & $\mathrm{A}$ & $\mathrm{A}$ \\
\hline Grafické symboly vyznačujúce určité časti textu & $\mathrm{A}$ & $\mathrm{A}$ \\
\hline $\begin{array}{l}\text { Využitie zvláštnej farby pre určité časti verbálneho } \\
\text { textu }\end{array}$ & & $\mathrm{A}$ \\
\hline $\begin{array}{l}\text { Využitie zvláštneho písma pre určité časti verbálneho } \\
\text { textu }\end{array}$ & $\mathrm{A}$ & $\mathrm{N}$ \\
\hline Využitie prednej (zadnej) obálky, schémy, tabul'ky atd'. & $\mathrm{N}$ & \\
\hline
\end{tabular}

Tabul'ka 3 Porovnanie komponentov orientačného aparátu

\begin{tabular}{|l|c|c|}
\hline & 1. učebnica & 2. učebnica \\
\hline Aparát orientačný & $\mathbf{3}$ & $\mathbf{2}$ \\
\hline Verbálne komponenty & 3 & 2 \\
\hline Obsah učebnice & $\mathrm{A}$ & $\mathrm{A}$ \\
\hline Členenie učebnice na tematické bloky, kapitoly & $\mathrm{A}$ & $\mathrm{A}$ \\
\hline Marginálie & $\mathrm{N}$ & $\mathrm{N}$ \\
\hline register & $\mathrm{A}$ & $\mathrm{N}$ \\
\hline
\end{tabular}

Tabul'ka 4 Porovnanie koeficientov jednotlivých aparátov

\begin{tabular}{|l|c|c|}
\hline & 1. učebnica & 2. učebnica \\
\hline Aparát prezentácie učiva & $\mathbf{1 2}$ & $\mathbf{1 2}$ \\
\hline Koeficient využitia aparátu prezentácie učiva & $85 \%$ & $85 \%$ \\
\hline Aparát riadiaci učenie & $\mathbf{7}$ & $\mathbf{1 1}$ \\
\hline Koeficient využitia aparátu riadiaceho učenie & $39 \%$ & $61 \%$ \\
\hline Aparát orientačný & $\mathbf{3}$ & $\mathbf{2}$ \\
\hline Koeficient využitia aparátu orientačného & $75 \%$ & $50 \%$ \\
\hline Verbálne komponenty & 14 & 17 \\
\hline Koeficient využitia verbálnych komponentov & $52 \%$ & $63 \%$ \\
\hline Obrazové komponenty & 8 & 8 \\
\hline Koeficient využitia obrazových komponentov & $89 \%$ & $89 \%$ \\
\hline Štruktúrne komponenty učebnice & $\mathbf{2 2}$ & $\mathbf{2 5}$ \\
\hline Celkový koeficient didaktickej vybavenosti učebnice & $\mathbf{6 1 \%}$ & $\mathbf{6 9 \%}$ \\
\hline
\end{tabular}


Z porovnania koeficientov pre jednotlivé aparáty vidíme, že aparát prezentácie učiva zostal na rovnakej úrovni, ale prišlo k výraznému zlepšeniu aparátu riadiaceho učenie - je tam nárast z $39 \%$ na $61 \%$. Naopak, v novej učebnici je pomerne nízky koeficient orientačného aparátu, kde prišlo k jeho zníženiu o $15 \%$ oproti predchádzajúcej učebnici. Pri podrobnejšom skúmaní zistíme, že využívanie verbálnych komponentov $\mathrm{v}$ učebnici predmetu technika vzrástlo, čím sa zlepšilo aj celkové využitie štruktúrnych komponentov učebnice.

\section{Záver}

Obe učebnice predmetu technika a technická výchova sú charakteristické tým, že nie sú tvorené pre konkrétny ročník základnej školy (resp. osemročného gymnázia). V prípade učebnice pre technickú výchovu je to dané filozofiou tvorcov učebnice, ktorí predpokladali, že učebnica pôjde so žiakom od piateho ročníka po deviaty, následne bude vyradená a žiakovi zostane ako sprievodca životom techniky. Preto je štruktúrovaná po tematických celkoch bez udania ročníka. V prípade učebnice pre predmet technika koncepcia učebnice odráža koncepciu tvorby školských vzdelávacích programov, v ktorých musí byt' predmet technika povinne zaradený v 7. a 8 . ročníku základnej školy a príslušných ročníkoch osemročných gymnázií, ale škola môže rozšírit' výučbu predmetu aj do 5., 6. a 9. ročníka. Preto boli autori učebnice nútení písat' ju nie po ročníkoch, ale tematických celkoch, ktoré splńajú obsahové štandardy predmetu.

\section{Literatura}

[1] PRŮCHA, J. Učebnice: teorie a analýzy edukačního média. Brno: Paido, 1998, 148s. ISBN 80-85931-49-4.

[2] PILLINGOVÁ, M. Didaktická vybavenost' aktuálnych učebníc dejepisu pre stredné odborné školy na Slovensku, v ČR a v Mad'arsku. In MVEK. Prešov: FHPV PU. 2011. s. 584 - 593. ISBN 978-80-555-0482-7

[3] KRUŠPÁN, I. a kol. Technická výchova pre 5. až 9. ročník základných škôl. Bratislava: Expol Pedagogika. 1999. ISBN 80-967957-4-0.

[4] ŠTEFANC, D. The Textbook from the Aspect of Didactic Theory: Characteristics, Function, Quality and Problems of Approving. In Journal of Contemporary Educational Studies. Ljubljana: Revija Sodobna pedagogika. Issue 4, 56/122, 2005.

[5] ŽÁČOK, L. - KUČERKA, M. - PAVLOVKIN, J. - ĎURIŠ, M. Technika pre 7. ročnik základnej školy a 2 ročník gymnázia s osemročným štúdiom. Banská Bystrica: TBB. 2012. ISBN 978-80-971037-0-5.

[6] Štátny vzdelávací program pre 2 stupeň základnej školy vSlovenskej republike. Bratislava: ŠPÚ, 2008.

doc. PaedDr. Danka Lukáčová, PhD.

Katedra techniky a informačných technológií

Pedagogická fakulta UKF

Dražovská cesta 4

94974 Nitra, SR

Tel: +421 376408342

E-mail: dlukacova@ukf.sk

http://www.ktit.pf.ukf.sk 